\title{
Matematik Eğitimi Sürecinde Sınıf Öğretmenlerinin Teknolojik Pedagojik Alan Bilgisine (TPAB) İlişkin Görüşleri' ${ }^{1}$
}

DOI: $10.26466 /$ opus.766702

\author{
Lütfi Üredi* - Hakan Ulum** \\ *Doç. Dr., Mersin Üniversitesi, Eğitim Fakültesi, Sınıf Eğitimi ABD \\ E-Posta: lutfiuredi@gmail.com ORCID: 0000-0003-1705-1325 \\ **Doktora Öğrencisi, Çukurova Üniversitesi, Sosyal Bilimler Enstitüsü, Sınıf Eğitimi ABD \\ E-Posta: hakanulum@gmail.com O ORCID: 0000-0002-1398-6935
}

$\ddot{O} z$

Teknolojik pedagojik alan bilgisi (TPAB) düzeyi yüksek öğretmenler, öğretim süresince alana özgü teknolojilerin kullanımına önem verir ve teknolojinin entegre edildiği bir sınıf ortamının nasıl olması gerektiği hakkında bilgilidir. Ayrıca çă̆ımız eğitim teknolojilerini matematik eğitim sürecinde öğrencileri ile etkileşimli olarak kullanarak bu doğrultuda öğrencilerin derse yönelik tutum, motivasyon ve başarılarının da artmasına katkı sağlayabilirler. Bu çalışmanın amacl, matematik eğitim sürecinde sını öğretmenlerinin teknolojik pedagojik alan bilgisine ait görüşlerinin tespit edilmesidir. Araştırmada nitel araştırma yöntemlerinden fenomenoloji deseni kullanılmıştır. Çalışma, 2019 yılında Mersin ili Tarsus ilçesinde görev yapmakta olan 25 sinı öğretmeni ile gerçekleştirilmiştir. Yarı yapılandırılmış görüşme formu kullanılarak toplanan veriler içerik analizine tâbi tutulmuştur. Araştırmada sınıf öğretmenlerinin öğretmen yeterlikleri hakkındaki düşünceleri ve TPAB algıları tespit edilmiştir. Ayrıca matematik öğretiminde kullanılması gereken teknolojik araç gereçler, bu araç gereçlerin kullanım nedenleri ve kullanım esnasında karşılaşılabilecek problemler hakkındaki görüşleri belirlenmiştir. Araştırmada sını öğretmenlerinin matematik öğretiminde kullanılabileceği strateji, yöntem ve teknikler ile kullanım nedenleri konusundaki düşünceleri de sorgulanmıştır. Elde edilen bulgular ışı̆̆ında araştırmacılara ve sını öğretmenlerine önerilerde bulunulmuştur.

Anahtar Kelimeler: Sını öğretmenleri, Teknolojik pedagojik alan bilgisi (TPAB), Matematik

${ }^{1}$ Bu çalışma 11-14 Nisan 2018'de gerçekleştirilen 17. Uluslararası Sını Öğretmenliği Sempozyumu'nda sözlü bildiri olarak sunulmuştur. 


\title{
Primary School Teachers' Views about Technological Pedagogical Content Knowledge (TPACK) in Mathematics Education Process
}

\begin{abstract}
Teachers with high level of technological pedagogical content knowledge (TPACK) attach importance to the use of domain specific technologies during teaching. They are knowledgeable about how a classroom environment in which technology is integrated should be. In addition, they can use the old education technologies as an interaction with the students in the mathematics education process and contribute to the students' attitudes towards the lessons, motivation and success. The aim of this study is to determine the opinions of technological pedagogical content knowledge of teachers in mathematics education process. Phenomenological model has been used in qualitative research methods. The study was conducted with 25 primary school teachers working in the province of Tarsus in Mersin province. The data collected using the semi-structured interview forms were subjected to content analysis. In the research, the thoughts of primary school teachers about teacher competencies and TPACK perceptions were determined. In addition, they have identified the technological tools that should be used in teaching mathematics, the reasons for their use, and the problems they may face during use. The researchers also questioned the strategies, methods and techniques that can be used in mathematics teaching by primary school teachers and the reasons for using them. Based on the findings, suggestions were made to researchers and classroom educators.
\end{abstract}

Keywords: Primary school teachers, Technological pedagogical content knowledge (TPACK), Mathematics 


\section{Giriş}

Ferhatoğlu (2014) PTC'nin (Principal Training Center) Amerika' da düzenlediği Teknoloji Liderliği eğitimine, dünyanın her köşesinden eğitimcilerin katıldığını ve bir sınıfta okullarda teknoloji entegrasyonunda en çok karşılaşılan problemlerin listelenmesi etkinliğinin yapıldığını belirtmiştir. Listeye göre sonuç okul dünyanın neresinde olursa olsun, en çok zorlanılan şey öğretmenin teknolojiyi derslerinde kullanamaması ve müfredata entegre edememesi olduğunu vurgulamıştır.

Eğitim-öğretimin kalitesi nitelikli öğretmenlerle artar. Müfredat ne kadar işlevsel oluşturulursa oluşturulsun eğitimin temel ögelerinden öğretmenler, bu alanda beklenen düzeyde olamaz ise istenilen değişimin gerçekleşmeyeceği ortadadır (Demirel ve Kaya, 2003). Ayrıca hangi yenilik yapılırsa yapılsın yenilikler öğretmenler tarafından iyi özümsenip faaliyete geçirilmedikçe başarılı olamaz (Baki, 2002). Müfredat ne kadar uygulanırsa uygulansın kontrol edilemeyen teknoloji öğretimi etkisiz kılar.

Matematik öğretiminde pedagojik yazılımları kullananların potansiyeli, öğretimi etkiler. Teknolojik gelişmelerin sunduğu sınıf ortamları öğretmeni bilgi aktarıcılı̆̆ından öğrenmeyi öğreticiliğe yöneltmiştir. Bu misyonu üstlenen öğretmenler, teknoloji bilgisini, deneyimi ve birikimi ile birleştirerek etkili olabilir (Baki, 2001).

Öğretmenler nitelikli öğretmen vasıflarına sahip olabilmek için teknolojinin kullanımı konusunda kendilerini iyi bir şekilde yetiştirmelidir. Matematik öğretim süreci, teknolojik araç ve gereçlerin kullanılabilmesi için uygun bir alan olarak nitelendirilir. Bu bağlamda matematik pedagojisiyle teknoloji kullanımının birleştirilerek sunulması gerekir (Öksüz, ak ve Uça, 2009). Yüksek Öğretim Kurumu (2011) Türkiye Yükseköğretim Yeterlilikler Çerçevesi kapsamında lisans düzeyindeki yetkinliklere dünyanın önde gelen bilgisayar kullanım yetkinliği sertifikası Avrupa Bilgisayar Yetkinlik Sertifikası'na ileri düzeyde sahip olunmasını gerektiğini belirtmiştir. Bununla beraber National Council of Teachers of Mathematics, (Amerikan Ulusal Öğretmenler Birliği) okul matematiği ilke ve standartları çerçevesinde teknolojinin matematik öğretiminde kullanılması gerektiğini belirtmiştir (NCTM, 2000).

Bu bağlamlarda öğretmenlere öğretim sürecinde teknoloji kullanımının öğretilmesi şarttır. TPAB bu anlamda önem kazanmaktadır. TPAB' in teme- 
linde, öğretmenlerin eğitim teknolojileriyle pedagojik alan bilgilerini kullanarak nasıl etkili bir şekilde öğretim yapabilecekleri vardır (Shulman, 1986;1987). Shulman (1986) tarafindan literatüre sunulan "pedagojik alan bilgisi" üzerine teknoloji bilgisinin ilave edilmesi ile kuramsallaştırılmıştır. $\mathrm{TPAB}$, son zamanlarda birçok ülkedeki öğretmen eğitimi ile ilgilenenlerin ilgisini çekmiştir (American Association of Colleges for Teacher Education, 2008).

Farklı araştırmacılar genellikle farklı TPAB yapısı ve bilgi alanları şemaları kullanmasına rağmen benzer fikirleri tartısmışlardır. TPAB' in yapısı ve bilgi alanlarına dair gösterim zaman içerisinde Mishra ve Koehler (2006) ve Koehler ve Mishra (2008) çalışmalarında şekillenerek en yaygın halini almıştır.

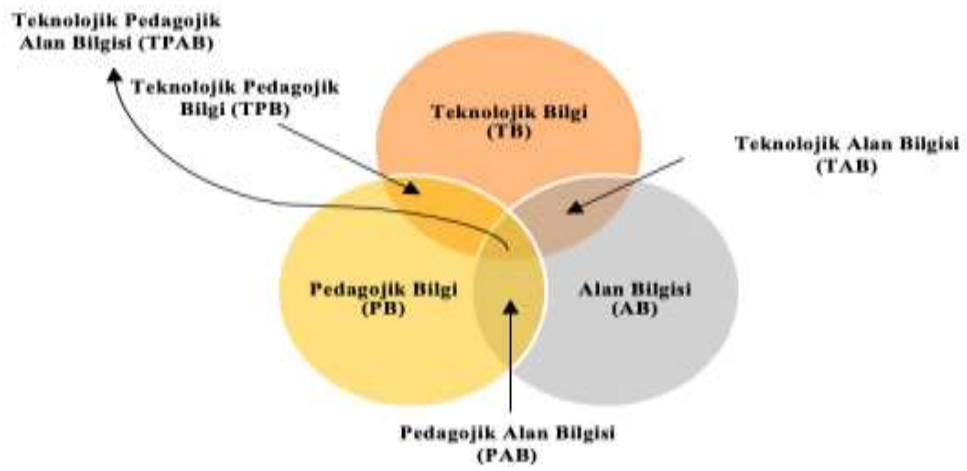

Şekil 1. TPAB Yapısı ve Bilgi Alanlarn (Kohler ve Mishra, 2009, s.63).

Bu modelde (bkz. Şekil 1), öğretmen bilgisinin üç ana bileşeni vardır: Alan (içerik), pedagoji ve teknoloji. Etkileşimli olan bu modelde teknolojik bilgi (TB), pedagojik bilgi $(\mathrm{PB})$ ve alan bilgisi $(\mathrm{AB})$ eşit derecede öneme sahiptir ve merkezinde TPAB bulunur (Kohler ve Mishra, 2009).

Teknolojik Bilgi (TB) : Teknoloji bilgisi, kalem ve kâğıt gibi düşük teknolojili teknolojilerden Internet, dijital video, interaktif yazı tahtaları ve yazılım programları gibi dijital teknolojilere kadar çeşitli teknolojiler hakkındaki bilgileri ifade eder (Schmidt, Baran, Thompson, Mishra, Koehler ve Shin, 2009). 
Alan bilgisi (AB): Öğretmenlerin öğrenilecek veya öğretilecek konu hakkındaki bilgisidir. İlkokulda ele alınacak içerik ortaokul ve lise derslerindeki içerikten farklıdır. İçerik bilgisi öğretmenler için kritik öneme sahiptir (Kohler ve Mishra, 2009).

Pedagojik Bilgi (PB) : Pedagojik bilgi, öğretme yöntemleri ve süreçlerini ifade eder ve sınıf yönetimi, değerlendirme, ders planı geliştirme ve öğrenci öğrenmede bilgi içerir (Schmidt ve ark., 2009).

Teknolojik Pedagojik Bilgi (TPB) : Belirli teknolojiler belirli şekillerde kullanıldığında öğretme ve öğrenmenin nasıl değişebileceğinin bir anlayışıdır. Disipliner ve gelişimsel olarak uygun pedagojik tasarımlar ve stratejilerle ilgili bir dizi teknolojik aracı pedagojik niteliklerini ve kısttlamaların bilmeyi içerir. TPB oluşturmak için, teknolojilerin kısıtlamalarını ve karşılanmasını ve işlev gördükleri disiplinsel bağlamları daha derinden anlamak gerekir (Kohler ve Mishra, 2009).

Teknolojik Alan Bilgisi (TAB) : Teknolojik alan (içerik) bilgisi, teknolojinin belirli içerik için nasıl yeni temsiller oluşturabileceğine dair bilgidir. Teknolojik alan (içerik) bilgisine sahip öğretmenler, belirli bir teknolojiyi kullanarak öğrencilerin belirli bir içerik alanında kavramları nasıl uyguladıklarını, anladıklarını ve değiştirebileceğini bilirler (Schmidt ve ark., 2009).

Pedagojik Alan Bilgisi (PAB) : Shulman'a (1987) göre PAB öğretmenlerin içerik bilgisini uygun pedagojik yaklaşımlarla nasıl birleştirecekleri konusundaki özgün bilgileridir.

Teknolojik Pedagojik Alan Bilgisi (TPAB) : Üç "temel" bileşenin (içerik, pedagoji ve teknoloji) ötesine geçen yeni bir bilgi biçimidir. Teknolojik pedagojik alan bilgisi; içerik, pedagoji ve teknoloji bilgisi arasındaki etkileşimlerden ortaya çıkan bir anlayıştır (Kohler ve Mishra, 2009). TPAB'a göre öğretmenler, uygun pedagojik yöntemler ve teknolojiler kullanarak içerik öğretmeli, bilginin üç temel bileşeni $(\mathrm{AB}, \mathrm{PB}, \mathrm{TB})$ arasındaki karmaşık etkileşimi sezebilmelidir (Schmidt ve ark., 2009).

Alanyazında TPAB ile ilgili eleştirilerde göze çarpmaktadır TPAB eğitim ile teknolojiyi bütünleştirme bilgisi olarak tasarlanmamıştır; ancak, bağlam 
içine koymak gerekir. Örneğin, ilkokuldan liseye kadar tüm eğitim seviyeleri çok farklıdır. TPAB'in seviyeye göre teknoloji entegrasyonuna yönelik yaklaşımları olabilir (Hobgood ve Ormsby, 2015; Roblyer ve Doering, 2010).

Araştırmanın genel amacı matematik eğitim sürecinde sınıf öğretmenlerinin teknolojik pedagojik alan bilgisine ait görüşlerinin tespit edilmesidir. Bu genel amaç doğrultusunda aşağıdaki sorulara cevap aranmıştır:

1. Sınıf öğretmenlerinin mesleki yeterlikleri neler olmalıdır? Neden?

2. Teknolojik Pedagojik Alan Bilgisi (TPAB) sizin için neyi ifade etmektedir?

3. Teknoloji bilgisi, pedagoji bilgisi ve alan bilgisinin birlikte kullanımı matematik öğretim sürecinde ne gibi sonuçlar doğurur?

4. Matematik öğretim sürecinde hangi teknolojik araç ve gereçlerin kullanılmasının gerekli olduğunu düşünüyorsunuz? Bu teknolojik araç ve gereçleri kullanırken nelere dikkat edilmelidir?

5. Teknolojik araç ve gereçleri kullandığınız matematik öğretim sürecinde ne gibi problemlerle karşılaşıyorsunuz?

6. Matematik öğretiminde genellikle hangi strateji, yöntem ve tekniklerden yararlanılabilir? Neden?

7. Matematik öğretiminde materyal kullanımının avantaj ve dezavantajları nelerdir?

Araştırmadan elde edilecek bulgular neticesinde ulaşılacak sonuçlarla öğretmenler ve ТРАВ konusunda araştırmacıların ve eğitimcilerin üzerinde farkındalık yaratılması hedeflenmiştir.

\section{Yöntem}

Araştırmada fenomenoloji [olgu bilim] deseninden yararlanılmıştır. Fenomenolojide, araştırmaya katılanların deneyimlerini nasıl algıladıkları onların ifadeleri ile anlaşılmaya çalışılır (McMillan, 2004; Richards ve Morse, 2007). Bu araştırmada matematik öğretim sürecinde sınıf öğretmenlerinin teknolojik pedagojik alan bilgisine ait görüşlerini onların açıklamalarıyla anlamak amaçlandığı için olgu bilim deseni tercih edilmiştir. Bununla birlikte fenomenoloji alanyazında "iki ucu keskin bir kılıç" olarak ifade edilir. Fenomenolojik araştırmalarda sorgulama ve analizi insan yapar. İnsan fak- 
törü bu bağlamda en büyük güç ve temel zayıflıktır (iki ucu keskin bir kılıç) (Patton, 2002).

\section{Çalışma Grubu}

Araştırmaya katılan katılımcilar 25 öğretmenden oluşmaktadır. Saban ve Ersoy' a göre (2017) olgu bilim çalışmalarında birtakım kaynaklar katılımcı sayısının 5 ile 25 arasında olmasının uygun düşeceğinden bahsederken, (Creswell, 2007) bazı kaynaklar en az 10 katılımcı olması gerektiğinden söz eder (Creswell, 2007; Yıldırım ve Şimşek, 2006). Bu araştırmada katılımcı sayısı 25 olarak tercih edilmiştir.

Araştırmanın katılımcıları belirlenirken "maksimum çeşitlilik örneklemesi" yönteminden yararlanmıştır. Buradaki amaç, göreli olarak küçük bir örneklem meydana getirmek ve bu çalışma grubunda araştırılan probleme taraf olabilecek katılımcıların çeşitliliğini en üst düzeyde yansıtmaktır (Yıldırım ve Şimşek, 2006). Araştırma amacı doğrultusunda Mersin il merkezi, Tarsus ilçe merkezi ve Mersin ili köylerinde 2019 yılında görev yapan öğretmenler seçilerek maksimum çeşitlilik sağlanmaya çalışılmıştır.

Çalışmaya katılan sınıf öğretmenlerinin demografik özellikleri tabloda verilmiştir.

Tablo 1. Demografik Bilgiler

\begin{tabular}{|c|c|c|c|c|}
\hline & & (f) & $\%$ & Toplam \\
\hline \multirow{2}{*}{ Cinsiyet } & Erkek & 12 & 48 & \multirow{14}{*}{25} \\
\hline & Kadın & 13 & 52 & \\
\hline \multirow{5}{*}{ Kıdem } & $0-5$ yıl & 4 & 16 & \\
\hline & $6-10$ yıl & 5 & 20 & \\
\hline & $11-15$ yll & 8 & 32 & \\
\hline & $16-20$ yil & 5 & 20 & \\
\hline & 20 yil üzeri & 3 & 12 & \\
\hline \multirow{4}{*}{ Okutulan Sınıf Düzeyi } & 1.Sinif & 6 & 24 & \\
\hline & 2.Sinif & 6 & 24 & \\
\hline & 3.Sinif & 7 & 28 & \\
\hline & 4.Sinif & 6 & 24 & \\
\hline \multirow{3}{*}{ Eğitim Durumu } & Ön Lisans & 3 & 12 & \\
\hline & Lisans & 20 & 80 & \\
\hline & Lisansüstü & 2 & 8 & \\
\hline
\end{tabular}




\section{Veri Toplama Araçları}

Fenomenoloji deseninde temel veri toplama tekniği görüşmedir. Olgulara ilişkin deneyim ve anlamları ortaya çıkarmada görüşme tekniği araştırmac1lara etkileşim, esneklik ve sondalar yoluyla irdeleme olanakları sunar (Yıld1rım ve Şimşek, 2006). Araştırmada da veriler, araştırmacılar tarafından geliştirilen yarı yapılandırılmış görüşme formu ile öğretmenlerden yüz yüze, bireysel toplanmıştır. Yarı yapılandırılmış görüşme formunda yer alan demografik bilgiler cinsiyet, kıdem, okutulan sınıf düzeyi ve eğitim durumudur. Formdaki sorular ise araştırmanın amacında verilmiştir (bakınız s.6).

Araştırmada yapılan kapsamlı bir literatür taraması sonucunda kavramsal bir çerçeve oluşturulmuştur. Yarı yapılandırılmış görüşme formları ile bu kavramsal çerçeve göz önünde tutulmuştur. Öğretmenlere yöneltilen açık uçlu sorular da bu kavramsal çerçeve kapsamında oluşturulmuş ve mevcut sorulara eklemek istedikleri bir husus olup olmadığ sorularak veriler toplanmıştır. Araştırmanın katılımclarına gönüllülük esasının olduğu söylenmiş ve kişisel bilgilerinin araştırmada geçmeyeceği taahhüt edilmiştir. $\mathrm{Bu}$ işlemler araştırmanın iç geçerliğini sağlamak açısından önemlidir.

Araştırmada yapılan kodlama ve kategori oluşturma işlemleri, verilerden yola çıkılarak araştırmacı ve alandan öğretim üyesi tarafından tekrarlı şekilde yapılmıştır. Araştırmanın problemi ve amacı göz önünde bulundurularak gereksiz kodlamalar çikarılmış ve yeni kodlamalar oluşturulmuştur. Verilerin güvenirliği Miles ve Huberman (1994) tarafından tavsiye edilen [Görüş birliği / (Görüş birliği + Görüş ayrıllğı)] x 100 formülü ile hesaplanmış ve verilerin güvenirliğini belirten uyuşum yüzdesi \% 84 olarak bulunmuştur. Bu değer verilerin güvenilir olduğunu göstermektedir.

Araştırmanın dış geçerliğini sağlamak açısından yarı yapılandırılmış görüşme formunun oluşturulması, yapılan görüşmeler ve analiz basamakları açıklanmaya çalışılmış; çalışma grubu, veri toplama aracı, süreci, verilerin çözümlenmesi ve yorumlanması okuyucuların anlayabileceği şekilde tanımlanmıştır. 


\section{Verilerin Analizi}

Fenomenoloji çalışmalarında veri analizi, yaşantıları ve anlamları ortaya çıarmaya yöneliktir. Bu amaçla yapılan içerik analizinde verinin kavramsallaştırılması ve olguyu tanımlayabilecek temaların ortaya çkarılması çabası vardır (Yıldırım ve Şimşek, 2006). Bu çalışmada elde edilecek veriler içerik analizine tabi tutulmuştur.

Yıldırım ve Şimşek' e göre (2006) içerik analizinde veriler şu dört aşamadan geçer:

1) Verilerin kodlanması

2) Temaların bulunması

3) Kodların ve temaların düzenlenmesi

4) Bulguların tanımlanması ve yorumlanması

$\mathrm{Bu}$ araştırmada veriler, toplanan verilerden çıkarılan kavramlara göre kodlanmıştır (verilerin kodlaması). Bu aşamada toplanan veriler tümevarımcı bir yaklaşımla, detaylı olarak incelenerek kodlar oluşturulmuştur. Oluşan kod listesi tüm verilerin işlenmesinde kavramsal yapıyı teşkil etmiştir. Oluşturulan kodlar bir araya getirilmiş ve tema arayışına girilmiştir. Kodlar arasında anlamlı ilişkiler kurulmuş ve temalar bulunmuştur (temaların bulunması). Sonraki aşamada verilerin anlaşılır bir hal alması için düzenlenmiş tanımlanmış, açıklanmıştır (kodların ve temaların düzenlenmesi). Analizin son aşamasında bulgular dikkatle yorumlanmıştır (bulguların tanımlanması ver yorumlanmasi).

\section{Bulgular}

Araştırma kapsamında elde edilen bulgular aşağıda sunulmuştur.

Tablo 2'den anlaşılacağı üzere sinıf öğretmenlerinde bulunması gereken mesleki yeterliklere ilişkin katılımcıların görüşleri; pedagoji bilgisine (\%54.25 sıklıkla), alan bilgisine (\%7.63 sıklıkla), pedagojik alan bilgisine (\%2.86 sıklıkla), teknoloji bilgisine (\%7.63 skklıkla), teknolojik alan bilgisine (\%0.95 sıklıkla), kişisel yeterliklere (\%13.34 sıklıkla) ve duyuşsal yeterliklere (\%13.34 sıklıkla) sahip olması gerektiğin yönündedir. 
Matematik Eğitimi Sürecinde Sınıf Öğretmenlerinin Teknolojik Pedagojik Alan Bilgisine (TPAB) İlişkin Görüşleri

Tablo 2. Sını öğretmenlerinde bulunması gereken mesleki yeterliklere ilişkin öğretmen algilar

\begin{tabular}{|c|c|c|c|c|}
\hline Tema & Kod & $\begin{array}{l}\text { Siklik } \\
\text { (f) }\end{array}$ & $\begin{array}{l}\text { Sıklık } \\
\text { Yüzdesi } \\
(\%)\end{array}$ & Yüzde (\%) \\
\hline Alan Bilgisi & Alan bilgisine sahip olmalı & 8 & 7.63 & 7.63 \\
\hline \multirow{8}{*}{$\begin{array}{l}\text { Duyuşsal } \\
\text { Yeterlik }\end{array}$} & $\begin{array}{l}\text { İnsani değerler barındırmalı (vicdan, merhamet } \\
\text { vb.) }\end{array}$ & 2 & 1.90 & \multirow{8}{*}{13.34} \\
\hline & Mesleğini sevmeli & 1 & 0.95 & \\
\hline & Çocukları sevmeli & 5 & 4.77 & \\
\hline & Empati kurabilmeli & 2 & 1.90 & \\
\hline & Sosyal olmalı & 1 & 0.95 & \\
\hline & Demokratik olmalı & 1 & 0.95 & \\
\hline & Enstrüman çalabilmeli & 1 & 0.95 & \\
\hline & Kitap okumalı & 1 & 0.95 & \\
\hline \multirow{6}{*}{$\begin{array}{l}\text { Kişisel } \\
\text { Yeterlik }\end{array}$} & Uyumlu biri olmalı & 1 & 0.95 & \multirow{6}{*}{13.34} \\
\hline & Mesleği ile ilgili yeniliklere açık olmalı & 7 & 6.67 & \\
\hline & Mesleğin gerektirdiği kişilikte olmalı & 1 & 0.95 & \\
\hline & Psikolojik özellikleri öğretmenliğe uygun olmalı & 3 & 2.86 & \\
\hline & Diksiyonu düzgün olmalı & 1 & 0.95 & \\
\hline & Problemlere çözüm getirebilmeli & 1 & 0.95 & \\
\hline $\begin{array}{l}\text { Pedagojik } \\
\text { Alan Bilgisi }\end{array}$ & Staj sürecini iyi geçirmeli & 3 & 2.86 & 2.86 \\
\hline \multirow{14}{*}{$\begin{array}{l}\text { Pedagojik } \\
\text { Bilgi }\end{array}$} & Sınıf yönetimi konusunda etkin olmalı & 12 & 11.42 & \multirow{14}{*}{54.25} \\
\hline & $\begin{array}{l}\text { Pedagoji bilgisine sahip olmalı (sınıf seviyesine } \\
\text { inmeli) }\end{array}$ & 14 & 13.33 & \\
\hline & Öğrencilerle etkili iletişim kurabilmeli & 6 & 5.71 & \\
\hline & Çocuk oyunlarıyla öğretim yapabilmeli & 2 & 1.90 & \\
\hline & Mesleğindeki güncellemeleri takip etmeli & 7 & 6.67 & \\
\hline & Çocuk psikolojisine hâkim olmalı & 1 & 0.95 & \\
\hline & Öğrenme sürecini iyi yönetmeli & 2 & 1.90 & \\
\hline & Çocukların bilişsel özelliklerini bilmeli & 1 & 0.95 & \\
\hline & Öğretim yöntem ve tekniklerini etkin kullanmalı & 3 & 2.86 & \\
\hline & Bireysel farklılıkların farkında olmalı & 1 & 0.95 & \\
\hline & $\begin{array}{l}\text { Bulunduğu coğrafyaya göre eğitim sürecini } \\
\text { şekillendirmeli }\end{array}$ & 1 & 0.95 & \\
\hline & Veli ile sağlıklı iletişim sağlayabilmeli & 4 & 3.80 & \\
\hline & Öğretimi planlı ve programlı yapmalı & 2 & 1.90 & \\
\hline & Yaratıcı drama bilgisine sahip olmalı & 1 & 0.95 & \\
\hline $\begin{array}{l}\text { Teknolojik } \\
\text { Alan Bilgisi }\end{array}$ & $\begin{array}{l}\text { Eğitim araç ve gereçlerini kullanmada yetkin } \\
\text { olmalı }\end{array}$ & 1 & 0.95 & 0.95 \\
\hline $\begin{array}{l}\text { Teknolojik } \\
\text { Bilgi }\end{array}$ & Teknoloji bilgisine sahip olmalı & 8 & 7.63 & 7.63 \\
\hline Toplam & & 105 & 100 & 100 \\
\hline
\end{tabular}


Bu bulgulardan hareketle sınıf öğretmenlerinin çoğunluğu; sınıf öğretmenlerinin öğrenci seviyesine inebilmesini (pedagoji bilgisine sahip olmalı), teknoloji bilgisine sahip olması gerektiğini, sınıf yönetimi konusunda etkin olması gerektiğini, alan bilgisine sahip olması gerektiğini vurgulamışlardır.

Sınıf öğretmenlerinden alınan bazı doğrudan alıntılar:

- K.16: Yeterli derecede alan bilgisine sahip olmah. Planlı ve düzenli olmahıdır. Çocuklarn çok sevmelidir. Demokratik olmalıdır. Dersi çocuklarm düzeyine uygun işlemelidir. Özgüveni yüksek olmahdır.

- K.19: Alan bilgisine sahip olmalıdır. Teknolojik ürünleri kullanmayı bilmelidir. Sinıf yönetimini bilmelidir. Öğretim programlarmdaki yenilikleri takip etmelidir.

Tablo 3. Öğretmenlerin Teknolojik Pedagojik Alan Bilgisine (TPAB) yönelik algılar

\begin{tabular}{|c|c|c|c|c|}
\hline Tema & Kod & $\begin{array}{l}\text { Siklık } \\
\text { (f) }\end{array}$ & $\begin{array}{l}\text { Siklık } \\
\text { Yüzdesi (\%) }\end{array}$ & $\begin{array}{l}\text { Yüzde } \\
\text { (\%) }\end{array}$ \\
\hline Alan Bilgisi & Teknolojik gelişmelerin çocuklara aktarılması & 1 & 4.00 & 4.00 \\
\hline $\begin{array}{l}\text { Pedagojik } \\
\text { Bilgi }\end{array}$ & $\begin{array}{l}\text { Öğrencilerin derse yönelik tutum, motivasyon ve başarılarının } \\
\text { artmasını sağlayan formasyon bilgisi }\end{array}$ & 1 & 4.00 & 4.00 \\
\hline \multirow{4}{*}{$\begin{array}{l}\text { Teknolojik } \\
\text { Alan Bilgisi }\end{array}$} & Kavram öğretiminde teknoloji kullanımı & 1 & 4.00 & \multirow{4}{*}{16.00} \\
\hline & Alandaki gelişmeler ve içeriğin teknoloji ile birleştirilmesi & 1 & 4.00 & \\
\hline & $\begin{array}{l}\text { Kaliteli eğitim için teknoloji ile alan bilgisinin sürekli olarak } \\
\text { yenilenmesi }\end{array}$ & 1 & 4.00 & \\
\hline & Teknolojiyi derslerde uygun kullanma becerisi & 1 & 4.00 & \\
\hline \multirow{5}{*}{$\begin{array}{l}\text { Teknolojik } \\
\text { Pedagojik } \\
\text { Alan Bilgisi }\end{array}$} & Teknolojik araçların derste öğrenci seviyesine uygun kullanımı & 3 & 12.00 & \\
\hline & $\begin{array}{l}\text { Alan bilgisini ve pedagoji bilgisini teknolojik ortamda etkin } \\
\text { kullanma }\end{array}$ & 1 & 4.00 & \\
\hline & $\begin{array}{l}\text { Teknolojik ve pedagojik bilgilerin birleştirilerek içeriğin akta- } \\
\text { rılması }\end{array}$ & 2 & 8.00 & 32.00 \\
\hline & $\begin{array}{l}\text { Dersin teknolojik araç ve gereçler kullanılarak ögrenci seviye- } \\
\text { sine uygun işlenme bilgisi }\end{array}$ & 1 & 4.00 & \\
\hline & $\begin{array}{l}\text { Ders içeriğini aktarırken teknolojik araçları, yöntem teknik } \\
\text { bilgisi ve sınıf yönetimi bilgisi ile birleştirmek }\end{array}$ & 1 & 4.00 & \\
\hline \multirow{6}{*}{$\begin{array}{l}\text { Teknolojik } \\
\text { Pedagojik } \\
\text { Bilgi }\end{array}$} & Teknolojinin eğitim öğretim sürecine entegrasyonu & 3 & 12.00 & \\
\hline & $\begin{array}{l}\text { Anlamlı öğrenmenin gerçekleşebilmesi için teknolojiyi bir araç } \\
\text { olarak kullanma }\end{array}$ & 3 & 12.00 & \\
\hline & Teknolojiyi çocuk gelişimini takip amacıyla kullanma & 1 & 4.00 & 44.00 \\
\hline & Teknolojik araçlar kullanılarak öğretme bilgisi & 1 & 4.00 & \\
\hline & $\begin{array}{l}\text { Öğretme sürecinin zamanını kısaltma adına pedagojik alan } \\
\text { bilgisinin teknoloji ile kullanılması bilgisi }\end{array}$ & 1 & 4.00 & \\
\hline & Eğitimde teknolojik ürünlerin kullanılması & 2 & 8.00 & \\
\hline Toplam & & 25 & 100 & 100 \\
\hline
\end{tabular}


Tablo 3'den anlaşılacağı üzere, sınıf öğretmenlerine göre Teknolojik Pedagojik Alan Bilgisi (TPAB); Teknolojik Pedagojik Bilgisi (\%44.00 sıklıkla), Teknolojik Pedagojik Alan Bilgisi (\%32.00 sıklıkla), Teknolojik Alan Bilgisi (\%16.00 sıklıkla), Pedagojik Bilgisi (\%4.00sıklıkla), Alan Bilgisi (\%4.00 sıklıkla) oluşturmaktadır. Bu bulgulardan hareketle sınıf öğretmenlerinin çoğunluğu, $\mathrm{TPAB}^{\prime}$ 1; teknolojik araçların derste öğrenci seviyesine uygun kullanımı, teknolojinin eğitim öğretim sürecine entegrasyonu, anlamlı öğrenmenin gerçekleşebilmesi için teknolojiyi bir araç olarak kullanma şeklinde tanımlamışlardır.

Sınıf öğretmenlerinden alınan bazı doğrudan alıntılar:

- K.17: Teknolojik pedagojik alan bilgisi anlamlı öğrenmenin gerçekleşmesi için teknolojinin eğitime entegrasyonunu sağlamaya yarar. Teknoloji ile eğitim birleştiğinde kalıc öğrenme daha kolay gerçekleşir.

- $\quad \mathrm{K}: 13$ : Dersi anlatırken bilgisayar, video, internet gibi araçlar öğrencilerin seviyesine uygun olarak etkin bir şekilde kullanmaktır.

Tablo 4. Teknoloji bilgisi, pedagoji bilgisi ve alan bilgisinin birlikte kullanımının matematik öğretim sürecinde ortaya çıkardı̆̆ı sonuçlara ilişkin öğretmen görüşleri

\begin{tabular}{|c|c|c|c|c|}
\hline Tema & Kod & $\begin{array}{l}\text { Siklık } \\
\text { (f) }\end{array}$ & $\begin{array}{l}\text { Siklık } \\
\text { Yüzdesi } \\
(\%)\end{array}$ & Yüzde $(\%)$ \\
\hline \multirow{2}{*}{$\begin{array}{l}\text { Bilişsel Becerilerin Kazan- } \\
\text { dırılmasına } \quad \text { Yönelik } \\
\text { Avantaj Sağlar }\end{array}$} & Problem çözme becerisini geliştirir & 1 & 1.82 & \multirow[b]{2}{*}{18.18} \\
\hline & Matematik başarısını arttırır & 9 & 16.36 & \\
\hline Duyuşsal Becerilerin & \multirow[b]{2}{*}{ Motivasyonu arttırır } & \multirow[b]{2}{*}{2} & \multirow[b]{2}{*}{3.64} & \multirow[b]{2}{*}{3.64} \\
\hline $\begin{array}{l}\text { Kazandırılmasına } \\
\text { Yönelik Avantaj Sağlar }\end{array}$ & & & & \\
\hline \multirow{2}{*}{$\begin{array}{l}\text { Öğrenme Ortamını Geliş- } \\
\text { tirmeye Yönelik } \\
\text { Avantaj Sağlar }\end{array}$} & \multirow{2}{*}{$\begin{array}{l}\text { Etkili, etkileşimli ve eğlenceli bir } \\
\text { öğrenme ortamı sağlar } \\
\text { Matematiği ilgi çekici kılar }\end{array}$} & 7 & 12.73 & \multirow[t]{2}{*}{16.37} \\
\hline & & 2 & 3.64 & \\
\hline \multirow{3}{*}{$\begin{array}{l}\text { Öğretim Niteliği } \\
\text { Arttırmaya Yönelik } \\
\text { Avantaj Sağlar }\end{array}$} & \multirow{3}{*}{$\begin{array}{l}\text { Kalıcı öğrenmeyi sağlar } \\
\text { Günlük hayata hazırlar } \\
\text { Görsel ve işitsel zenginlik sağlar, } \\
\text { somutlaştırır }\end{array}$} & 8 & 14.54 & \multirow{3}{*}{40.00} \\
\hline & & 1 & 1.82 & \\
\hline & & 13 & 23.64 & \\
\hline \multirow{3}{*}{$\begin{array}{l}\text { Matematik Öğretimi } \\
\text { Sürecini Kolaylaştırır }\end{array}$} & Öğrenme ve öğretmeyi kolaylaştırır & 8 & 14.54 & \multirow{3}{*}{21.81} \\
\hline & Yaratıcılık ve pratiklik kazandırır & 1 & 1.82 & \\
\hline & Zamandan tasarruf ettirir & 3 & 5.45 & \\
\hline Toplam & & 55 & 100 & 100 \\
\hline
\end{tabular}

Tablodan anlaşılacağı üzere teknoloji bilgisi, pedagoji bilgisi ve alan bilgisinin birlikte kullanımının matematik öğretim sürecinde ortaya çıkardığı sonuçlara ilişkin sınıf öğretmenlerinin görüşleri; öğretim niteliği arttırmaya 
yönelik avantaj sağlar (\%40.00 sıklıkla), matematik öğretimi sürecini kolaylaştırır (\%21.81 sıklıkla), bilişsel becerilerin kazandırılmasına yönelik avantaj sağlar (\%18.18 sıklıkla), öğrenme ortamını geliştirmeye yönelik avantaj sağlar (\%16.37 sıklıkla), duyuşsal becerilerin kazandırılmasına yönelik avantaj sağlar (\%3.64 sıklıkla) yönündedir. Bu bulgulardan hareketle sinıf öğretmenlerinin çoğunluğu, , teknoloji bilgisi, pedagoji bilgisi ve alan bilgisinin birlikte kullanımının matematik öğretim sürecinde ortaya çıkardığı sonuçlar olarak; matematik başarısını arttırdığı, görsel ve işitsel zenginlik sağlayıp, somutlaştırdığı, kalıc öğrenmeyi sağladığı, öğrenme ve öğretmeyi kolaylaştırdığı şeklinde sıralamışlardır.

Sınıf öğretmenlerinden alınan bazı doğrudan alıntılar:

- K.15: Teknolojik, pedagojik ve alan bilgisinin bir arada kullanımı; ulaşılması gereken amaca daha az sürede ulaşılmasım sağlayacaktır. Bu durumda kahıc ve sürekli öğrenme kolaylaşacă̆̆ gibi öğrenme içgüdüsünü tetikler, daha fazla öğrenme gerçekleşir.

- K.17: Matematikte soyut kavramlar somutlaştırma, öğrenmenin kahıı olması, görsellerle desteklenen eğitimin daha verimli olması sonuçlarını doğurur.

Tablo 5. Matematik öğretiminde hangi teknolojik araç ve gereçlerin kullanılmasının gerekliliğine ilişkin öğretmen görüşleri

\begin{tabular}{|c|c|c|c|c|}
\hline Tema & Kod & $\begin{array}{l}\text { Siklık } \\
\text { (f) }\end{array}$ & $\begin{array}{l}\text { Sıklık } \\
\text { Yüzdesi } \\
\text { (\%) }\end{array}$ & Yüzde (\%) \\
\hline \multirow{7}{*}{$\begin{array}{l}\text { Bilişim } \\
\text { Teknolojileri } \\
\text { Araç } \\
\text { ve Gereçleri }\end{array}$} & İnternet & 8 & 14.03 & \multirow{7}{*}{82.42} \\
\hline & Tablet & 4 & 7.01 & \\
\hline & Bilgisayar & 9 & 15.78 & \\
\hline & Akillı telefon & 1 & 1.76 & \\
\hline & Projeksiyon & 7 & 12.27 & \\
\hline & Bilgisayar yazılımları & 3 & 5.26 & \\
\hline & Akıllı tahta & 15 & 26.31 & \\
\hline \multirow{8}{*}{$\begin{array}{l}\text { Geleneksel } \\
\text { Araç ve } \\
\text { Gereçler }\end{array}$} & Tepegöz & 1 & 1.76 & \multirow{8}{*}{17.58} \\
\hline & Cetvel & 2 & 3.51 & \\
\hline & Pergel & 1 & 1.76 & \\
\hline & Ders kitapları & 1 & 1.76 & \\
\hline & Yardımcı kitaplar & 1 & 1.76 & \\
\hline & Dereceli silindir & 2 & 3.51 & \\
\hline & Terazi & 1 & 1.76 & \\
\hline & Kalem, defter & 1 & 1.76 & \\
\hline Toplam & & 57 & 100 & 100 \\
\hline
\end{tabular}


Yukarıdaki tablodan anlaşılacağı üzere, matematik öğretiminde hangi teknolojik araç ve gereçlerin kullanılmasının gerekliliğine ilişkin sınıf öğretmenlerinin görüşleri; Bilişim Teknolojileri Araç ve Gereçleri (\%82.42 s1klıkla) ve Geleneksel Araç ve Gereçler (\%17.58 sıklıkla) yönündedir. Bu bulgulardan hareketle sınıf öğretmenlerinin çoğunluğu, matematik öğretiminde kullanılması gereken teknolojik araç ve gereçleri; akıllı tahta, bilgisayar, internet, projeksiyon olarak saymışlardır.

Sınıf öğretmenlerinden alınan bazı doğrudan alıntılar:

- K.25: Projeksiyon, bilgisayar veya akıll tahta üzerinden görseller ve programlar.

- K.16: Cetvel, geometrik cisimler, pergel, ders kitaplar, yardımo kitaplar.

Tablo 6. Matematik öğretiminde teknolojik araç ve gereçleri kullanırken dikkat edilmesi gereken hususlara ilişkin öğretmen görüşleri

\begin{tabular}{|c|c|c|c|c|}
\hline Tema & Kod & $\begin{array}{l}\text { Siklık } \\
\text { (f) }\end{array}$ & $\begin{array}{l}\text { Sıklık } \\
\text { Yüzdesi } \\
\text { (\%) }\end{array}$ & $\begin{array}{l}\text { Yüzde } \\
(\%)\end{array}$ \\
\hline \multirow{4}{*}{$\begin{array}{l}\text { Öğretim } \\
\text { Niteliği } \\
\text { Arttırmaya } \\
\text { Yönelik } \\
\text { Hususlar }\end{array}$} & Geleneksel eğitim araçları ile birlikte kullanılmasına & 3 & 8.82 & \multirow{4}{*}{47.07} \\
\hline & Uygun zamanda uygun teknolojik araçların kullanımı & 4 & 11.77 & \\
\hline & İlgi çekici eğlenceli olmasına & 5 & 14.71 & \\
\hline & Somutlaştırarak kolaylaştırıcı olmasına & 4 & 11.77 & \\
\hline \multirow{4}{*}{$\begin{array}{l}\text { Pedagojik } \\
\text { Bilgi İçerikli } \\
\text { Hususlar }\end{array}$} & Planlama ve hazırlık yapmaya & 2 & 5.88 & \multirow{4}{*}{41.17} \\
\hline & Seviyeye uygun olmasina & 2 & 5.88 & \\
\hline & Amaca uygun olmasına & 9 & 26.47 & \\
\hline & Düşünmeye teşvik etmeli & 1 & 2.94 & \\
\hline $\begin{array}{l}\text { Sağlık } \\
\text { Tedbirleri }\end{array}$ & Sağlığı olumsuz etkilememesine & 1 & 2.94 & 2.94 \\
\hline Teknik & Uygun alt yapının sağlanmasına & 1 & 2.94 & \multirow{2}{*}{8.82} \\
\hline Konular & Kötü amaçlı içerik ve yazılımlar için tedbir alınmasına & 2 & 5.88 & \\
\hline Toplam & & 34 & 100 & 100 \\
\hline
\end{tabular}

Tablo 6'dan anlaşılacağı üzere matematik öğretiminde teknolojik araç ve gereçleri kullanırken dikkat edilmesi gereken hususlara ilişkin sınıf öğretmenlerinin görüşleri; öğretim niteliği arttırmaya yönelik hususlar (\%47.07 sıklıkla), pedagojik bilgi içerikli hususlar (\%41.17 sıklıkla), teknik konular (\%8.82 sıklıkla), sağlık tedbirleri (\%2.94 sıklıkla) yönündedir. Bu bulgulardan hareketle sınıf öğretmenlerinin çoğunluğu, matematik öğretiminde teknolojik araç ve gereçleri kullanırken dikkat edilmesi gereken hususları; 
amaca uygun olmasına, ilgi çekici eğlenceli olmasına, uygun zamanda uygun teknolojik araçların kullanımı olarak belirtmişlerdir.

Sınıf öğretmenlerinden alınan bazı doğrudan alıntılar:

- K.7: Burada dikkat edilmesi gereken nokta amacm kesinlikle oyuna dönüşmemesi, amacın kazanım olmasıdır.

- K.13: Bazı soyut kavramları somutlaştırmalarına ve ilgi çekici olmasına dikkat edilmelidir.

Tablo 7. Matematik öğretim sürecinde teknolojik araç ve gereç kullanırken karşılaşılan problemlere ilişkin öğretmen görüşleri

\begin{tabular}{|c|c|c|c|c|}
\hline Tema & Kod & $\begin{array}{l}\text { Sıklık } \\
\text { (f) }\end{array}$ & $\begin{array}{l}\text { Siklık } \\
\text { Yüzdesi } \\
(\%)\end{array}$ & Yüzde (\%) \\
\hline \multirow{6}{*}{$\begin{array}{l}\text { Pedagojik Bilgi } \\
\text { Eksikliği }\end{array}$} & Dikkat dağınıklığı & 4 & 12.12 & \multirow{6}{*}{63.63} \\
\hline & Uzun süreli kullanımda öğrencilerin sıkılması & 1 & 3.03 & \\
\hline & $\begin{array}{l}\text { Öğrenci sayısındaki fazlalığa bağlı uygulama yeter- } \\
\text { sizlikleri }\end{array}$ & 6 & 18.18 & \\
\hline & Zaman yönetimi zorluğu & 4 & 12.12 & \\
\hline & Öğrenci ve öğretmeni pasifleştirme & 5 & 15.15 & \\
\hline & Öğrenci seviyesini yakalayamama & 1 & 3.03 & \\
\hline \multirow{4}{*}{$\begin{array}{l}\text { Teknik / } \\
\text { Donanımsal } \\
\text { Problemler }\end{array}$} & Alt yapı sorunları (elektrik, internet kesintileri vb.) & 7 & 21.21 & \multirow{4}{*}{33.33} \\
\hline & Araç ve gereçlerin muhafaza edilememesi & 2 & 6.06 & \\
\hline & Yazılım hataları & 1 & 3.03 & \\
\hline & Uygun yazılım bulma zorluğu & 1 & 3.03 & \\
\hline $\begin{array}{l}\text { Teknolojik } \\
\text { Bilgi Eksikliği }\end{array}$ & $\begin{array}{l}\text { Teknolojik yetkinlik eksikliğinden kaynaklı zorlan- } \\
\text { ma }\end{array}$ & 1 & 3.03 & 3.03 \\
\hline Toplam & & 33 & 100 & 100 \\
\hline
\end{tabular}

Tabloya göre, matematik öğretim sürecinde teknolojik araç ve gereç kullanırken karşılaşılan problemlere ilişkin sınıf öğretmenlerinin görüşleri; pedagojik bilgi eksikliği (\%63.63 sıklıkla), teknik / donanımsal problemler (\%33.33 sıklıkla), teknolojik bilgi eksikliği (\%3.03 sıklıkla) yönündedir. Bu bulgulara dayanarak sınıf öğretmenlerinin çoğunluğu, matematik öğretim sürecinde teknolojik araç ve gereç kullanırken karşılaştığı problemleri; alt yapı sorunları (elektrik, internet kesintileri vb.), öğrenci sayısındaki fazlalığa bağlı uygulama yetersizlikleri, öğrenci ve öğretmeni pasifleştirme olarak belirtmişlerdir.

Sınıf öğretmenlerinden alınan bazı doğrudan alıntılar:

- K.1: Öğrenciyi pasifleştiriyor. 
- K.5: En büyük problem elektrik kesintisidir. Ders internet üzerinden işleniyorsa internet kesintisi de problem olmaktadır. Kalabalık sinfflarda teknolojik araçlar korumak büyük sıkıntı oluyor.

- K.25: Öğrenciler yazılım, bilgisayar ya da akıllı tahta kullanımında yeterli değilse karışıklık çıkabilir. Elektrik kesintisi, internet kesintisi de süreci yavaşlatır.

Tablo 8. Matematik öğretiminde kullanılan strateji, yöntem ve tekniklere ilişkin öğretmen görüşleri

\begin{tabular}{|c|c|c|c|c|}
\hline Tema & Kod & $\begin{array}{l}\text { Siklık } \\
\text { (f) }\end{array}$ & $\begin{array}{l}\text { Siklık } \\
\text { Yüzdesi } \\
(\%)\end{array}$ & Yüzde (\%) \\
\hline \multirow{3}{*}{ Strateji } & Buluş yoluyla öğrenme & 12 & 13.63 & \multirow{3}{*}{19.31} \\
\hline & Sunuş yoluyla öğrenme & 3 & 3.41 & \\
\hline & Araştırma inceleme yoluyla öğrenme & 2 & 2.28 & \\
\hline \multirow{6}{*}{ Teknik } & Gösterip yaptırma & 8 & 9.10 & \multirow{6}{*}{44.33} \\
\hline & Soru cevap & 12 & 13.63 & \\
\hline & Grup (akran) çalışması & 3 & 3.41 & \\
\hline & Problem çözme & 11 & 12.50 & \\
\hline & Benzetim (simülasyon) & 2 & 2.28 & \\
\hline & Beyin fırtınası & 3 & 3.41 & \\
\hline \multirow{6}{*}{ Yöntem } & Oyunlarla öğretim & 4 & 4.54 & \multirow{6}{*}{30.68} \\
\hline & Anlatım yöntemi & 12 & 13.63 & \\
\hline & Bilgisayar destekli eğitim & 3 & 3.41 & \\
\hline & Rol oynama & 3 & 3.41 & \\
\hline & Drama & 3 & 3.41 & \\
\hline & Örnek olay inceleme & 2 & 2.28 & \\
\hline Yaklaşım & Yaparak yaşayarak öğrenme & 5 & 5.68 & 5.68 \\
\hline Toplam & & 88 & 100 & 100 \\
\hline
\end{tabular}

Tablo 8'den anlaşılacağı üzere, matematik öğretiminde kullanılan strateji, yöntem ve tekniklerin kullanımına ilişkin sınıf öğretmenlerinin görüşleri; teknik (\%44.33 sıklıkla) strateji (\%30.68 sıklıkla), yöntem (\%19.31 sıklıkla) yönündedir. Bu bulgulardan hareketle sinıf öğretmenlerinin çoğunluğu, matematik öğretiminde kullanılan strateji, yöntem ve teknikleri; buluş yoluyla öğrenme stratejisi, soru cevap tekniği, problem çözme tekniği, anlatım yöntemi olarak belirtmişlerdir. Bunun yanında kullanılan yaklaşım olarak, yaparak yaşayarak öğrenmeyi (\%5.68 sıklıkla) vurgulamışlardır.

Sınıf öğretmenlerinden alınan bazı doğrudan alıntılar:

- K.23: Sunuş yoluyla öğretim stratejisi, buluş yoluyla öğretim stratejisi, araştırma-inceleme yoluyla öğretim stratejisi, anlatım yöntemi, problem çözme, benzetim (simülasyon), drama, beyin firtınası, örnek olay inceleme. 
- K.16: Soru-cevap, problem çözme, anlatım; ders programın daha iyi şekilde uygulamak ve bilgileri vermek

Tablo 9. Matematik öğretiminde materyal kullanımınn avantajlarna ilişkin öğretmen görï̌şleri

\begin{tabular}{|c|c|c|c|c|}
\hline Tema & Kod & $\begin{array}{l}\text { Siklık } \\
\text { (f) }\end{array}$ & $\begin{array}{l}\text { Sıklık } \\
\text { Yüzdesi } \\
\text { (\%) }\end{array}$ & Yüzde (\%) \\
\hline \multirow{3}{*}{$\begin{array}{l}\text { Öğretim Niteliğine } \\
\text { Yönelik Avantajlar }\end{array}$} & Öğrenmeyi somutlaştırması & 13 & 39.39 & \multirow{3}{*}{84.85} \\
\hline & İlgi ve dikkat çekici olması & 6 & 18.18 & \\
\hline & Kalıcı öğrenmeyi sağlaması & 9 & 27.27 & \\
\hline $\begin{array}{l}\text { Matematik Öğretimi } \\
\text { Sürecini Kolaylaştırmaya } \\
\text { Yönelik Avantajlar }\end{array}$ & $\begin{array}{l}\text { Öğrenme ve öğretmeyi } \\
\text { kolaylaştırması }\end{array}$ & 5 & 15.15 & 15.15 \\
\hline Toplam & & 33 & 100 & 100 \\
\hline
\end{tabular}

Tablo 9'a göre, matematik öğretiminde materyal kullanımının avantajlarına ilişkin sınıf öğretmenlerinin görüşleri; öğretim niteliğine yönelik avantajlar (\%84.85 sıklıkla), matematik öğretimi sürecini kolaylaştırmaya yönelik avantajlar (\%15.15 sıklıkla) yönündedir. Bu bulgulardan hareketle sınıf öğretmenlerinin çoğunluğu, matematik öğretiminde materyal kullanımının avantajlarını; öğrenmeyi somutlaştırması, kalıcı öğrenmeyi sağlaması, ilgi ve dikkat çekici olması, öğrenme ve öğretmeyi kolaylaştırması olarak belirtmişlerdir.

Sınıf öğretmenlerinden alınan bazı doğrudan alıntılar:

- K.13: Birden fazla duyuya hitap ettiği için öğrenmenin kalıcıllğını sağlar; öğrenciler konuyu ezberleyerek değil, mantı̆̆ı anlayarak öğrenir. Ĕ̆er kullamlan materyaller öğrencinin ilgisini çekiyorsa çok etkili olur.

- K.22: Matematik öğretiminde materyal kullanımı dersin daha kahıı öğrenilmesini sağlar.

Tablo 10. Matematik öğretiminde materyal kullanımının dezavantajlarnna ilişkin öğretmen görüşleri

\begin{tabular}{|c|c|c|c|c|}
\hline Tema & Kod & Sıklık (f) & $\begin{array}{l}\text { Siklık Yüzdesi } \\
\text { (\%) }\end{array}$ & Yüzde (\%) \\
\hline \multirow{4}{*}{$\begin{array}{l}\text { Öğretim Niteli- } \\
\text { gine Yönelik } \\
\text { Dezavantajlar }\end{array}$} & Dikkat dağınıklı̆̆ı & 2 & 12.50 & \multirow{4}{*}{100.00} \\
\hline & Öğrenci ve öğretmeni pasifleştirmesi & 5 & 31.25 & \\
\hline & Zamanı iyi kullanamama & 6 & 37.50 & \\
\hline & Pahalı olması & 3 & 18.75 & \\
\hline Toplam & & 16 & 100 & 100 \\
\hline
\end{tabular}


Tablo 10 'dan anlaşılacağ 1 üzere matematik öğretiminde materyal kullanımının dezavantajlarına ilişkin sını öğretmenlerinin görüşleri öğretim niteliğine yönelik dezavantajlar (\%100.00 sıklıkla) yönündedir. Bu bulgulardan hareketle sınıf öğretmenlerinin çoğunluğu, matematik öğretiminde materyal kullanımının dezavantajlarını; zamanı iyi kullanamama, öğrenci ve öğretmeni pasifleştirmesi, pahalı olması, dikkat dağınıklı̆̆ına yol açma olarak belirtmişlerdir.

Sınıf öğretmenlerinden alınan bazı doğrudan alıntılar:

- K.2: Maliyeti fazla olabilir, tam olarak amaca hizmet edemeyebilir, öğretmeni pasifleştirebilir.

- K.22: Kalabalık sinıflarda sürenin yetmemesi sıkıntı olabilir.

\section{Tartışma, Sonuç}

Yapılan bu çalışmada sınıf öğretmenlerinin matematik öğretiminde TPAB'a yönelik görüşleri ortaya çıarılmaya çalışılmıştır. Bu bağlamda öncelikle sınıf öğretmenlerinin mesleğe yeni başlayan bir sınıf öğretmeninde bulunması gerektiğini düşündüğü yeterlikler; pedagoji bilgisi, alan bilgisi, pedagojik alan bilgisi, teknoloji bilgisi, teknolojik alan bilgisi, kişisel yeterlikler ve duyuşsal yeterlikler olduğu tespit edilmiştir. Tespiti yapılan bu görüşler arasında sınıf öğretmenlerinde bulunması gereken yeterlikler arasında TPAB yoktur. Sınıf öğretmenlerinin TPAB'a değinmemiş olmaları, bu bilgi türünden haberdar olmadıklarını işaret eder. Sınıf öğretmenlerinin çoğunluğu, sınıf öğretmenlerinin öğrenci seviyesine inebilme yetkinliğine (pedagoji bilgisine), teknoloji bilgisine, sinıf yönetimi konusunda etkin olması gerektiğine, alan bilgisine sahip olması gerektiğine vurgu yapmışlardır. Çelik ve Kahyaoğlu (2007), öğretmen adaylarının teknolojinin olanaklarından tam anlamıyla yararlanmasında teknolojiye karşı bakış açılarının çok önemli olduğunu vurgulamıştır. Bu bağlamda mesleğe başlamadan önce öğretmen adaylarına teknolojiye karşı olumlu tutum geliştirmelerini sağlamak önemlidir. Christensen ve Knezek'in (2000) yaptığı çalışmada öğretmen adaylarının eğitimde teknoloji kullanımına ilişkin tutumlarının düşük olduğu vurgulanmıştır. Bu tutumun geliştirilmesi amacıyla, deneysel bir çalışma yapmışlardır. Deney grubundaki aday öğretmenlere notebook ve eğitim yazılımı tedarik etmişlerdir. Bu teknolojik araçları öğretim sürecinde 
kullanmalarını talep etmişlerdir. Araştırmada ulaşılan sonuçlara göre; teknoloji ile etkileşim halinde olan ve sıkça teknolojiyi öğretim sürecinde kullanan öğrencilerin teknolojiye karşı tutumlarının yükseldiği gözlenmiştir. Teknolojinin öğretim sürecindeki önemini kavrayabilen aday öğretmenler, bu doğrultuda ilerleyerek alan eğitiminde teknolojiyi aktif kullanan öğretmenler olacaklardır.

Sınıf öğretmenlerinin TPAB hakkındaki algılarına bakılacak olunursa katılımclların Teknolojik Pedagojik Bilgisi, Teknolojik Pedagojik Alan Bilgisi, Teknolojik Alan Bilgisi, Pedagojik Bilgisi, Alan Bilgisine ilişkin açklamalarda bulundukları görülmüştür. Bu bulgulara dayanarak sınıf öğretmenlerinin TPAB'a ilişkin düşünceleri sorulduğunda çoğu, teknolojik araçların derste öğrenci seviyesine uygun kullanımı, teknolojinin eğitim-öğretim sürecine entegrasyonu, anlamlı öğrenmenin gerçekleşebilmesi için teknolojiyi bir araç olarak kullanma şeklinde ifade etmişlerdir. Burada sınıf öğretmenlerinin çoğu teknolojinin eğitim ortamında kullanılması ile ilişkilendirmede bulunmuştur. Alan yazın incelendiğinde öğretmen ve aday öğretmenlerin teknolojik bilgisinin olmasının ve bu bilgisini sinif ortamında uygun bir biçimde kullanılmasının yerinde olacağı belirtilmiştir (Koehler ve Mishra, 2005; Koehler ve Mishra, 2008).

Sınıf öğretmenleri; matematik öğretim sürecinde teknoloji bilgisi, pedagoji bilgisi ve alan bilgisinin birlikte kullanımının sonucunda öğretim niteliğinin artacağına, öğretim sürecinin kolaylaşacağına, bilişsel becerilerin kazandırılmasına, öğrenme ortamını nın geliştirilmesine, duyuşsal becerilerin kazandırılmasına yönelik avantaj sağlayacağına kanaat getirmişlerdir. Alan yazın incelendiğinde öğretmenlerin ve öğretmen adaylarının öğretim teknolojilerinin kullanımının faydalı olduğu konusunda hemfikir oldukları görülmektedir (Ayvacı, Er, Şenel ve Nas, 2007; Baki, Yalçınkaya, Özpınar ve Uzun, 2009; Yeşilyurt, 2006).

Araştırmada sınıf öğretmenleri teknolojik araç ve gereç olarak bilişim teknolojileri araç ve gereçlerinden yararlanırken, bir kısmının geleneksel araç ve gereçlerden yararlandığ 1 sonucuna ulaşılmıştır. Sınıf öğretmenlerinin çoğunluğu, matematik öğretiminde teknolojik araç ve gereç olarak akıllı tahta, bilgisayar, internet, projeksiyondan yararlandıklarını ifade etmişlerdir. Baki ve arkadaşları (2009) yaptıkları çalışmada öğretmenlerin en çok haberdar oldukları ve kullandıkları öğretim teknolojilerinin bilgisayar ve internet gibi yaygın kullanılan teknolojik ürünler olduğuna dikkat çekmiş- 
tir. İşman (2002) öğretmenlerle yürüttüğü araştırmasında öğretmenlerin en çok kullandığı teknolojik araç gerecin yazı tahtası ve kitap olduğu, yazılımların öğretmenler tarafından bilinmediği, yazıcı, tepegöz ve tarayıcının da kullanılmadığı sonucu bu çalışmanın sonucuyla ters düşmektedir. Yeşilyurt (2006) yaptığı araştırmada öğretmenlerin çoğunluğunun bilgisayar, tepegöz, video, radyo-teyp kullandıkları, diğer elektronik araç gereçleri daha az kullandıkları sonucuna varmıştır.

Araştırmada sınıf öğretmenlerinin matematik öğretiminde teknolojik araç ve gereçleri kullanırken dikkat edilmesi gereken hususlar olarak; öğretim niteliği arttırmaya yönelik, pedagojik bilgi içerikli, teknik konular, sağlık tedbirleri sonuçlarına ulaşılmıştır. Bu bulgulardan hareketle sınıf öğretmenlerinin çoğunluğu, matematik öğretiminde teknolojik araç ve gereçleri kullanırken dikkat edilmesi gereken hususlarl; amaca uygun olmasl, ilgi çekici eğlenceli olması, uygun zamanda uygun teknolojik araçların kullanılması olarak tespit etmişlerdir.

Araştırmada ulaşılan başka bir sonuç ise sınıf öğretmenlerinin matematik öğretim sürecinde teknolojik araç ve gereç kullanırken karşılaştı̆̆ problemlerle ilgilidir. Sını öğretmenleri problemleri pedagojik bilgi eksikliğinden kaynaklı, teknik / donanımsal problemler, teknolojik bilgi eksikliğinden kaynaklı problemler olarak ifade etmişlerdir. Sınıf öğretmenlerinin çoğunluğu, matematik öğretim sürecinde teknolojik araç ve gereç kullanırken karşılaştı̆̆ problemleri; alt yapı sorunları (elektrik, internet kesintileri vb.), öğrenci sayısındaki fazlalığa bağlı uygulama yetersizlikleri, öğrenci ve öğretmeni pasifleştirme olarak vurgulamışlardır. Fiziki alt yapı yetersizlikleri matematikle beraber diğer derslerde de teknoloji ile öğretim sürecini olumsuz etkilemektedir. Üredi, Akbaşlı ve Ulum (2016) ilköğretim okulu öğretmenlerinin eğitim platformlarının öğretimdeki kullanımına ilişkin görüşlerini araştırmak amac ile yaptığı çalışmada, öğretmenlerin tamamının eğitim platformlarını öğretimde (matematikle beraber diğer dersler) kullanmaya çalıştıkların belirtmişlerdir. Ancak ilkokullarda öğretmenler eğitim platformlarını, imkân olduğu sürece eğitim faaliyetlerinde kullandığını, öğretmenlerin fiziki alt yapının yetersiz olduğu görüşünde olduklarını belirtmişlerdir.

Araştırmanın sınıf öğretmenlerinin matematik öğretiminde kullanılan strateji, yöntem ve tekniklerin kullanımına ilişkin sonuçlarına göre öğretmenler; tekniklerden, stratejilerden ve yöntemlerden yararlanmaktadır. 
Bunlar çoğunlukla buluş yoluyla öğrenme stratejisi, soru cevap tekniği, problem çözme tekniği, anlatım yöntemidir. Bunun birlikte yaklaşım olarak yaparak yaşayarak öğrenmeyi kullandıklarını vurgulamışlardır. Burada yaklaşım belirtmelerinin nedeni yaparak yaşayarak öğrenmeyi strateji, yöntem veya teknik grubuna dâhil etmiş olmaları düşünülmektedir. Aktepe, Tahiroğlu, Acer (2015) öğretmenlerinin kullandığı öğretim yöntemleri ilişkin öğrenci görüşlerini inceledikleri çalışmada, matematik öğretiminde "en fazla" kullanılan öğretim yöntemi sırasıyla problem çözme, düz anlatım ve soru cevap yöntemi olduğunu tespit etmişlerdir. Toptaş (2012) yaptığı araştırmada öğretmenlerin en çok düz anlatım, soru-cevap ve problem çözme yöntemlerini kullandıkları sonucuna ulaşmıştır. Yavuz (2006), çalışmasında problem çözme yönteminin öğrencilerin matematik tutum puanları ve problem çözmeye yönelik akademik benlik puanlarının artmasında etkili olduğunu vurgular. Temizöz ve Özgün Koca (2010) yaptıkları araştırmanın gözlem raporlarına göre, öğretmenlerin derslerde en fazla soru-cevap tekniğini, sunuş yoluyla öğretme yaklaşımını, tartışma ve düzanlatım yöntemlerini kullandıkları tespit edilmiştir.

Araştırmada sınıf öğretmenleri matematik öğretiminde materyal kullanımının avantajlarını; öğretim niteliğini arttırmaya yönelik, matematik öğretimi sürecini kolaylaştırmaya yönelik olarak ifade etmişlerdir. Bu bağlamda sınıf öğretmenlerinin çoğunluğu, matematik öğretiminde materyal kullanımının avantajlarını; öğrenmeyi somutlaştırması, kalıcı öğrenmeyi sağlaması, ilgi ve dikkat çekici olması, öğrenme ve öğretmeyi kolaylaştırması olarak belirtmişlerdir. Araştırmanın bir diğer sonucuna göre sınıf öğretmenleri matematik öğretiminde materyal kullanımının dezavantajların öğretim niteliğine yönelik olarak belirtmişlerdir. Bu dezavantajları zamanı iyi kullanamama, öğrenci ve öğretmeni pasifleştirmesi, pahalı olması, dikkat dağınıklığı olarak sıralamışlardır. Üredi, Akbaşlı ve Ulum (2016) ilköğretim okulu öğretmenlerinin yaptığı çalışmada bilişim teknolojileri ürünü olan eğitim platformlarının en fazla matematik derslerinde kullanıldığını ve konuların somutlaştırılması, eğlenceli hale gelmesi ve öğrenmeyi kolaylaştırması yönünden avantaj sağladığını vurgulamışlardır. Çağıltay, Çakıroğlu, Çağıltay, Çakıroğlu (2001) çalışmasında eğitimde bilgisayar kullanmanın avantajlı olduğunu vurgulamıştır. Odabaşı, Çoklar, Kıyıcı ve Akdoğan (2002), web destekli eğitimin, ilkokul öğrencilerine uyarıcılık ve soyut kavramları so- 
mutlaştıran zengin bir eğitim ortamı sunduğunu da ortaya koymuştur. Söz konusu sonuçlar bu araştırma sonuçlarıyla örtüşmektedir.

\section{Öneriler}

Araştırma sonuçları doğrultusunda bazı öneriler getirilmiştir:

- Sinff Öğretmenlerine $T \mathrm{TPB}^{\prime}$ a yönelik online eğitimler verilebilir.

- Akademisyenler tarafından sınıf öğretmenlerine yönelik TPAB projeleri düzenlenebilir.

- $\quad \mathrm{Bu}$ araştırmada sınıf öğretmenlerinin görüşleri incelendiğinde sınıf öğretmenlerinin sahip olmaları gereken yeterlikler arasında $\mathrm{TPAB}^{\prime}$ a yer verilmediği tespit edildiği için, sınıf öğretmenlerinin bu bilgi türünden haberdar olmadıkları düşünülmektedir. Dolayısıyla sınıf öğretmenlerinin hizmet öncesi dönemde sahip olmaları gerektiği düşünülen yeterliklerden biri olan $\mathrm{TPAB}^{\prime}$ a ilişkin bilgi sahibi olmalarını sağlayacak uygulamalara derslerde yer verilmelidir. 


\title{
EXTENDED ABSTRACT
}

\section{Primary School Teachers' Views about Technological Pedagogical Content Knowledge (TPACK) in Mathematics Education Process}

\author{
Lütfi Üredi - Hakan Ulum \\ Mersin University, Çukurova University
}

It is imperative to teach the use of technology to teachers in the teaching process. TPACK gains importance in this sense. The basis of TPACK is how teachers can effectively teach by using educational technologies and pedagogical field knowledge (Shulman, 1986; 1987). It was theorized by the addition of technology knowledge on "pedagogical content knowledge" presented to the literature by Shulman (1986). TPACK has recently attracted the attention of those interested in teacher education in many countries (American Association of Colleges for Teacher Education, 2008).

In the literature, TPACK stands out in criticism about TPACK. however, it must be put into context. For example, all levels of education from primary school to high school are very different. TPACK may have approaches to technology integration according to the level (Hobgood \& Ormsby, 2015; Roblyer and Doering, 2010).

The general purpose of the study is to determine the opinions of classroom teachers on technological pedagogical content knowledge in the mathematics education process. In line with this general purpose, the following questions were sought:

1. What should be the professional competencies of classroom teachers? Why is that?

2. What does Technological Pedagogical Content Knowledge (TPACK) mean to you?

3. What are the consequences of using technical knowledge, pedagogical knowledge, and field knowledge together in the mathematics teaching process?

4. Which technological tools and materials do you think it is necessary to use in the mathematics teaching process? What should be considered when using these technological tools and equipment? 
5. What kind of problems do you encounter in your mathematics teaching process where you use technological tools and equipment?

6. Which strategies, methods, and techniques can generally be used in teaching mathematics? Why is that?

7. What are the advantages and disadvantages of using materials in mathematics teaching?

With the results to be obtained as a result of the findings of the research, it was aimed to raise awareness among teachers and researchers and educators about TPACK.

In the research, phenomenology [phenomenology] design was used. In phenomenology, how the participants perceive their experiences is tried to be understood with their expressions (McMillan, 2004; Richards and Morse, 2007). In this study, phenomenology design was preferred because it was aimed to understand the opinions of classroom teachers on technological pedagogical content knowledge in the mathematics teaching process with their explanations.

Participants in the research consist of 25 teachers. According to Saban and Ersoy (2017), while some sources mention that the number of participants should be between 5 and 25 in phenomenology studies (Creswell, 2007), some sources mention that there should be at least 10 participants (Creswell, 2007; Yıldırım \& Şimşek, 2006 ). In this study, the number of participants was chosen as 25 .

While determining the participants of the research, they made use of the "maximum diversity sampling" method. The aim here is to create a relatively small sample and to reflect the diversity of the participants who may be a party to the problem investigated in this study group (Yıldırım and Şimşek, 2006). In line with the purpose of the research, it was tried to provide maximum diversity by choosing teachers working in Mersin city center, Tarsus district center, and Mersin province villages in 2019.

In the phenomenology design, the basic data collection technique is an interview. Interview technique in revealing the experiences and meanings of the cases provides the researchers with interaction, flexibility, and opportunities to examine them through probes (Yıldırım and Şimşek, 2006). In the study, data were collected from teachers face to face, individually, using a semi-structured interview form developed by the researchers. The demographic information in the semi-structured interview form is gender, senio- 
rity, school level, and education status. The questions in the form are given in the purpose of the research (see p.6).

A conceptual framework was created as a result of a comprehensive literature review in the study. This conceptual framework was taken into consideration with semi-structured interview forms. Open-ended questions directed to teachers were also created within the scope of this conceptual framework and the data were collected by asking whether there is an issue they want to add to the existing questions. The participants of the study were told that it was voluntary and that their personal information would not be included in the research. These procedures are important in terms of ensuring the internal validity of the research.

The coding and category creation processes in the research were made repeatedly by the researcher and the faculty member based on the data. Considering the problem and purpose of the research, unnecessary codings were removed and new codings were created. The reliability of the data was calculated using the formula [Agreement / (Agreement + Disagreement)] $x$ 100 recommended by Miles and Huberman (1994), and the percentage of agreement indicating the reliability of the data was found to be $84 \%$. This value shows that the data are reliable.

To ensure the external validity of the research, the semi-structured interview form, interviews, and analysis steps were tried to be explained; The working group, data collection tool, process, analysis, and interpretation of the data are defined in a way that the readers can understand.

In phenomenology studies, data analysis is aimed at revealing experiences and meanings. For this purpose, there is an effort to conceptualize the data and reveal the themes that can define the phenomenon in the content analysis (Yildırım and Şimşek, 2006). The data obtained in this study were subjected to content analysis.

According to Yıldırım and Şimşek (2006), data goes through the following four stages of content analysis:

1) Coding of data

2) Finding themes

3) Editing codes and themes

4) Description and interpretation of the findings

In this study, the data were coded according to the concepts derived from the collected data (data coding). The data collected at this stage were 
analyzed in detail with an inductive approach and codes were formed. The resulting code list has formed the conceptual structure in the processing of all data. The codes created were brought together and a theme was searched. Significant relationships were established between the codes and themes were found (finding themes). In the next step, the data is defined and explained (editing codes and themes) arranged to make the data understandable. At the last stage of the analysis, the findings were carefully interpreted (description and interpretation of the findings).

In this study, it was tried to reveal the opinions of classroom teachers about TPACK in mathematics teaching. In this context, firstly, the qualifications that classroom teachers think that a new classroom teacher should have; Pedagogical knowledge, field knowledge, pedagogical content knowledge, technology knowledge, technological field knowledge, personal competencies, and affective competencies were determined. Among these opinions, TPACK is not among the competencies that should be found in classroom teachers. The fact that classroom teachers do not refer to TPACK indicates that they are not aware of this type of information. Most of the classroom teachers emphasized that classroom teachers should have the competence to reach student level (pedagogy knowledge), technology knowledge, effective classroom management, and field knowledge.

\section{Kaynakça / References}

Aktepe, V., Tahiroğlu, M., ve Acer, T. (2015). Matematik öğretiminde kullanılan öğretim yöntemlerine ilişkin öğrenci görüşleri. Nevşehir Hacı Bektaş Veli Üniversitesi, Sosyal Bilimler Enstitüsü Dergisi, 4, 127-143.

American Association of Colleges of Teacher Education (AACTE) (2008). Handbook of technological pedagogical content knowledge (TPCK) for educators. New York: Routledge/Taylor ve Francis Group.

Ayvacı, H. Ş., Er Nas, S., Şenel, T., ve Nas, H. (2007). Öğretmen adaylarının öğretim teknolojilerini kullanmaya yönelik düşünceleri ve bu teknolojileri kullanma yeterlilikleri.7th International Educational Technology Conference, Near East University.

Baki, A. (2001). Bilişim teknolojisi ışığı altında matematik eğitiminin değerlendirilmesi. Milli Eğitim Dergisi, 149(1), 26-31.

Baki, A., Yalçınkaya, H., Özpınar, İ., ve Uzun, S. (2009). İlköğretim matematik öğretmenleri ve öğretmen adaylarının öğretim teknolojilerine bakışlarının 
karşılaştırılması. Turkish Journal of Computer and Mathematics Education (TURCOMAT), 1(1), 65-83.

Büyüköztürk, Ş., Çakmak, E. K., Akgün, Ö. E., Karadeniz, Ş., ve Demirel, F. (2016). Bilimsel araştırma yöntemleri (22. Bask1). Ankara: Pegem Akademi.

Christensen, R. ve Knezek, G., (2000). Internal consistence reliabilities for 14 computer attitude scales. Journal of Technology and Teacher Education, 8(4), 327-336.

Çağıltay K, Çakıroğlu J, Çağıltay N, Çakıroğlu E (2001). Öğretimde bilgisayar kullanımına ilişkin öğretmen görüşleri. Hacettepe Üniversitesi Ĕ̆itim Fakültesi Dergisi, 21(21), 19-28.

Çelik, H.C. ve Kahyaoğlu, M. (2007). İköğretim öğretmen adaylarının Teknolojiye yönelik tutumlarının kümeleme analizi. Türk Eğitim Bilimleri Dergisi, 5(4), 571-586.

Denise A. Schmidt, Evrim Baran, Ann D. Thompson, Punya Mishra, Matthew J. Koehler ve Tae S. Shin (2009) Technological pedagogical content knowledge (TPACK). Journal of Research on Technology in Education, 42(2), 123-149.

Hobgood, B. ve Ormsby, L. (2015) NC Learn: Inclusion in the 21st-century classroom: Differentiating with technology - http://www.learnnc.org/lp/editions/every-learner/6776 Erişim Tarihi: 20.01.2019

İşman, A. (2002). Sakarya ili öğretmenlerinin eğitim teknolojileri yönündeki yeterlilikleri. The Turkish Online Journal of Educational Technology, 1(1), 72-92.

Koehler, M. J., ve Mishra, P. (2005). What happens when teachers design educational technology? The development of technological pedagogical content knowledge. Journal of Educational Computing Research, 32(2), 131-152.

Koehler, M., ve Mishra, P. (2008). Introducing TPCK. In. AACTE committee on innovation and technology (Eds.), Handbook of Technological Pedagogical Content Knowledge (TPCK) for Teaching and Teacher Educators, (p. 3-29). New York and London: Routledge.

Koehler, M., ve Mishra, P. (2009). What is technological pedagogical content knowledge (TPACK)?. Contemporary issues in technology and teacher education, 9(1), 60-70.

Miles, M. B., ve Huberman, A. M. (1994). Qualitative data analysis: An expanded sourcebook. Sage.

Odabaşı F, Çoklar AN, Kıyıc M, Akdoğan EP (2002). İköğretim birinci kademede web üzerinden ders işlenebilirliği. Turkish Online, 4(4), 182-190.

Öksüz, C., Ak, Ş., ve Uça, S. (2009). İköğretim matematik öğretiminde teknoloji kullanımına ilişkin algı ölçeği. Yüzüncü Yıl Üniversitesi Eğitim Fakültesi Dergisi, 6(1), 270-287. 
Patton, M. Q. (2002). Qualitative research ve evaluation methods (3rd ed.). Thousand Oaks, CA: Sage.

Roblyer, M.D. ve Doering, A. (2010). Integrating educational technology into teaching (5th Ed.). Boston, MA: Pearson Education, Inc.

Temizöz, Y., ve Özgün Koca, S. (2010). Matematik öğretmenlerinin kullandıkları öğretim yöntemleri ve buluş yoluyla öğrenme yaklaşımı konusundaki görüşleri. Ĕ̆itim ve Bilim, 33(149), 89-103.

Toptaş, V. (2012). Elementary school teachers' opinions on instructional methods used in mathematics classes. Ĕgitim ve Bilim, 37(166), 116-128.

Üredi, L., Akbaşl1, S., ve Ulum, H. (2016). Investigating the primary school teachers' perspectives on the use of education platforms in teaching. Educational Research and Reviews, 11(15), 1432-1439.

Yavuz, G (2006). Dokuzuncu sinı matematik dersinde problem çözme strateji öğretiminin duyuşsal özellikler ve erişiye etkisi. Yayımlanmamış Doktora Tezi, Dokuz Eylül Üniversitesi, İzmir.

Yeşilyurt, E. (2006). Öğretmenlerin öğretim araç ve gereçlerini kullanma durumlarmı etkileyen faktörler. Yayınlanmamış Yüksek Lisans Tezi, Firat Üniversitesi Sosyal Bilimler Enstitüsü, Elazığ.

Yıldırım, A., ve Şimşek, H. (2008). Nitel araştırma yöntemleri. (7. Baskı). Ankara: Seçkin Yayıncilı.

\section{Kaynakça Bilgisi / Citation Information}

Üredi, L. ve Ulum, H. (2020).Matematik eğitimi sürecinde sınıf öğretmenlerinin teknolojik pedagojik alan bilgisine (tpab) ilişkin görüşleri. OPUS-Uluslararası Toplum Araştırmaları Dergisi, 16(Özel Say1),3642-3669.DOI: 10.26466/opus.766702 